\title{
The Regent Business Schools New Entrepreneurial Centre: Towards Transforming South Africa's Past and Reformulating the Present
}

\author{
Anis Mahomed Karodia (MPH, MBA, PhD) ${ }^{1}$, Dhiru Soni (DPhil) ${ }^{2}$, Ahmed Shaikh (MBA) ${ }^{3}$ \\ ${ }^{1}$ Professor, Senior Academic and Researcher, Regent Business School, Durban, Republic of South Africa \\ ${ }^{2}$ Professor and Director of Research, Regent Business School, Durban, Republic of South Africa \\ ${ }^{3}$ Managing Director, Regent Business School, Durban, Republic of South Africa
}

\begin{abstract}
The paper looks at entrepreneurship in terms of its importance to South Africa. In this regard it discusses the importance of initiatives like the Regent Business Schools proposed new Entrepreneurial Centre which will be opened in the latter part of 2016. A brief historical perspective is undertaken in this regard, in order to firstly situate the thrust, importance and necessity of the entrepreneurship and entrepreneurial dynamic, as it relates to a democratic South Africa. This is undertaken within the context of development and leadership in South Africa. The importance of entrepreneurship cannot be under estimated, in terms of development and economic growth in South Africa for purposes of stimulating much needed small business development and, the empowerment of the masses of people neglected by the administrative government systems by both, the apartheid and democratic government, post 1994. In undertaking the discussion in this paper, the issues towards transforming South Africa's past and transforming the present assumes significance, in terms of the transformation agenda of the state. In addition the paper very briefly discusses development theories, and calls for a reformulation of these theories in order, to engineer sustained and coordinated development within developing countries. The paper outlines the strategic plan for the Regent Business Schools Centre for Entrepreneurship and its modalities for engagement for purposes of consolidating this important and necessary initiative. By the same token, the paper discusses very briefly the problems that higher education confronts in respect to access into higher education in South Africa and, therefore, posits that entrepreneurial training and development can assist in solving some problems that the country confronts, in terms of access to higher education and entrepreneurial development.
\end{abstract}

Keywords: Business, Entrepreneurship, Transforming, Reformulating, Economy, Education

\section{RESEARCH METHODOLOGY}

The paper does not use the classical research methodology generally used in research. This is premised on the basis that it attempts to situate the subject matter in this paper through the use of books; research articles presented by others, some newspaper articles used to ground the title of the paper as background reading, and synthesizes the discussions in terms of the critical responses received from the other two authors. In so doing the principal author assembled the paper using the critical inputs of the co - authors and relied on his own analysis and documentation provided by the Regent Business School in outlining its vision for the proposed new Entrepreneurial Centre. The paper looked into some critical aspects of transforming South Africa's past and suggests the reformation of the present education system, in terms of the broad development imperatives required by the country. In so doing a number of important issues are raised in the paper that contributes to the debates that currently permeate small business development in the country and access to higher education.

\section{THEORETICAL FrAMEWORK}

The theoretical framework is grounded on the basic premise that entrepreneurial development must become a fundamental intervention strategy within government policy and, the faculties of higher education within public universities, and private providers of higher education institutions in South Africa. By the same token the private sector and the corporates involved in business must, become cardinal players in respect to entrepreneurial development and, in terms of providing experiential training, providing the necessary resources and ultimately providing job opportunities and, thereby contributing to much needed economic growth and the empowerment of

${ }^{1}$ Corresponding Author: akarodia@regent.ac.za 
those that have lacked opportunity in the past to become entrepreneurs because of apartheid policies. The lack of support from the democratic government, post 1994 in respect of entrepreneurship and business development, especially for the black population of South Africa. The theoretical framework must and will inform the epistemology and ontology in a historical perspective of the much needed new paradigm of business, particularly small business and entrepreneurial education and training at both private and public higher education institutions and business corporations in South Africa.

\section{ETHICAL CONSIDERATIONS}

Given the fact that not much has been done by the government, the private sector, public and private higher education institutions in terms of the much needed entrepreneurial development in South Africa, the paper therefore places on record that there are no finite ethical considerations within this paper, save to say that the discussion might be considered to be hard hitting to certain audiences. This is not aimed as criticism but places the negative objective realities with reference to entrepreneurship, and leadership within South Africa. It is hoped that the paper will broaden discussion and lend itself to other researchers conducting more rigorous research in this direction.

\section{FINDINGS}

There are no specific findings given the research methodology used in the construction of this paper. For all intents and purposes the findings are dispersed throughout the paper. It is hoped that this paper will contribute to the raging debate on entrepreneurship, development and access to higher education in South Africa.

\section{Creativity Value}

The creative value of this paper cannot be under estimated because of its value to the development of South Africa in terms of education, empowerment of the deprived masses and, for intervention strategies required for small business development and, more importantly to entrepreneurship understanding and, development, in a country that has very high unemployment, increasing inequality and poverty. The creativity value has to be appreciated by government and, the private sector, including Business Schools and institutions of higher learning in South Africa. Government, the private sector, public and private higher education institutions, must be charged with the responsibility of supporting, entrepreneurial initiatives of higher private academic institutions, such as the Regent Business School, who are attempting to redress the past imbalances created by apartheid and colonialism. It is an attempt to train and empower people to join the mainstream economy, in order to stimulate the South African economy. This will and can be achieved by engineering meaningful entrepreneurial and experiential learning, by means of practical application of more than meaningful and relevant entrepreneurial activity, exposure, and understanding in the application and implementation of a sound theoretical foundation, in engaging different types of entrepreneurial activity.

\section{INTRODUCTION}

"Historical consciousness ought to assist one to understand the possibilities of transformation and the possibilities within people" (E.P. Thompson, in Marho, 1983: 16). $\{1\}$

It is against the background of the above quotation that this paper will be nuanced and discussed. This will be undertaken, because of its relevance to contemporary South African society, particularly post the 1994 democracy, and the emergence from apartheid and colonial oppression. Therefore, the importance of the concept of entrepreneurship, to the development of both South Africa and the sum total of its people, and particularly to the emergence of Black citizens and women cannot be underestimated, nor paid scant reference to by the government, the public and private sectors and interested constituencies. By the same token, it must be clearly understood by policy makers within the government, the government itself, and the private sector of South Africa, that "South Africa has consistently scored the lowest in world rankings and performance, in respect to entrepreneurial activity" $\{25\}$. This situation has to be reversed and turned around for obvious reasons; most importantly for the purposes of the empowerment of South Africa's population, for economic growth and economic stability. Some of the discussions that permeate the entrepreneurial dynamics are nuanced in this paper. In so doing the Regent Business School has identified this major problem and challenge in South Africa, and to this end, in terms of its contribution to entrepreneurial development, has set the trajectory of addressing this fundamental concern, by the establishment and development of a new state of the art Entrepreneurial Centre.

"In a country like South Africa, given its colonial and apartheid past, the majority who do not speak English, which at the language level and medium, are important considerations at all levels of engagement and to entrepreneurship, 
leadership, business and general development, and the economic growth of an emerging economy" $\{2\}$. The enhancement of skills development, entrepreneurial development through training and insights to the needs of the people are therefore, important. This is most important and vital to South African intellectual business development. There have to be concerted efforts to "encourage people to learn language skills, coupled with the language used in business and, at the same time acquire deeper awareness of the circumstances they find themselves in, and the events that they experience and, have experienced and, the problems and challenges that they face in their everyday lives" $\{3\}$. It is thus obvious that, it can hardly be emphasised that the consideration of audiences, in a complex and divided society such as ours is most problematic. In this regard Luli Callinicos $\{5\}$ states that "Most members of South Africa's working class are of recent origin and the class is therefore, not cohesive; it is also deliberately divided further, along racial and ethnic lines by the state," even though South Africa attained democracy in 1994; it is further fragmented by management strategies perpetuated by the privileged classes that control the economy and also the means of production. This situation in a new and emerging democracy therefore, hinders the much needed growth trajectory and developmental momentum.

These divisions are easily exploited and do not allow the entrepreneurial spirit to emerge, consolidate itself and surface because, of a lack of an understanding of business, especially among small traders and business owners, including those that have been historically excluded, marginalized and left behind, in a country pregnant with small business opportunities and possibilities in the urban, rural and township settings. Since 2008 and recently in January 2015, it resulted in violence and xenophobic attacks against foreign small shop traders in some of South Africa's townships. This has been the result of sheer frustration on the part of small local business traders, post 1994, who feel neglected by the government, receive no assistance in respect of starting small businesses and are further frustrated by a lack of service delivery at the most basic levels. The government's inability over 21 years of democracy to deal with high levels unemployment, increasing poverty and widening inequality is a matter of deep and very serious concern. Entrepreneurial understanding, activity and training in this direction therefore, presents immense possibilities to engineer a turnaround strategy for purposes of making a sizeable contribution to self sufficiency of individuals and families, to marginalized and unemployed youth, in order to drive much needed economic growth and, in some ways contribute to bringing down the high rates of unemployment. This must not be seen as criticism, but rather construed as the reality that confronts South Africa and, if not dealt with decisively could lead to devastating consequences for peace, stability and the much needed growth of the economy. The intervention strategy therefore, requires a purposeful analysis of the situation, in order to redress this imbalance.

In the light of this scenario, the Regent Business School, a private higher education (distance) institution in South Africa is registered with the Department of Higher Education (DHE) and the Council on Higher Education (CHE). It has begun a process and, also chartered a framework to tackle the problem of the lack of the entrepreneurial spirit, especially among Black traders, the youth, and those desirous of entering the small business arena in South Africa, with particular reference to the province of KwaZulu - Natal and, the Port City of Durban and, other destinations. How does it intend intervening in some small measure to assist the KwaZulu - Natal Province, the Port City of Durban and its environs, other rural areas and, the small business trader and owner, to understand business modalities and the processes of business in general and, how to begin with starter small business initiatives? The process of building a state of the art entrepreneurial centre in Durban, attached to its Business School in the centre of the Port City of Durban, has begun and, it is hoped to open the doors of this centre towards the end of 2016. It has been the vision of a small coterie of staff led by the Managing Director Mr Ahmed Shaikh and, this vision has been consolidated and supported by the founding father of the institution Professor Yusuf Mahomed Karodia, a distinguished academic and teacher and, supported by management of the institution, academics attached to the school and the general administrative staff. (An in - depth discussion on the entrepreneurial centre will be undertaken in another part of the discussion in this paper).

In spite of the economic melting pot created by the swift rise post 1994 of South African capitalism, which is still controlled by outsiders and predominantly local Whites and, large corporates that have imbibed a minority of Blacks, in order, to look politically correct in empowering Blacks economically, and in order to curry favour with the government; the rise of a Black middle class and, the concomitantly rapid rise of a productive Black working class, now shows, major differences in background, culture and, the rural, urban and township experience have created major conflicts. "Rural and township communities in South Africa have suffered and they have been broken up by the past migrant labour system and were moved to and resettled in barren places" $\{6\}$. This has stymied the evolution and development of a Black entrepreneurial class in South Africa, at both the small and large business entities within the country. 


\section{ENTREPRENEURSHIP AND ECONOMIC DEVELOPMENT}

It is widely accepted that the term "Entrepreneurship" lacks a universal definition and we thus attempt briefly, to clarify its description; scholars have applied various adjectives to the word entrepreneurship to create a sub domain - terms such as "corporate entrepreneurship," "social entrepreneurship," "opportunity entrepreneurship" and "necessity entrepreneurship. These terms provide greater clarity when specifying subject populations and enable research to focus on and explore different aspects of Entrepreneurship" \{18). Regardless of its description, entrepreneurship appears to play a key role in developing and developed economies alike. Therefore, "entrepreneurs create new businesses and new business in turn creates jobs. High levels of entrepreneurship will thus translate into higher levels of economic development and growth in the macro economy" $\{19,20\}$. Van Praag and Versloot $\{21\}$ "are of the opinion that entrepreneurs contribute to economic development, growth and sustainability through four main categories, namely (i) Employment generation, (ii) innovation, (iii) productivity and growth, and, (iv) increasing individuals' utility levels. Entrepreneurship is responsible for employment creation, productivity growth and producing important spill - over's that affect local employment growth rates in a given region in the long run. Berglund (2005) "suggests that entrepreneurs disrupt prevailing equilibria in economic markets through innovation, thereby changing various economic benchmarks, enabling growth within the economy" $\{22\}$. It must be remembered however that those who do not directly engage in entrepreneurship cannot be ignored because they account for a high percentage value of GDP. "It is therefore most important that entrepreneurial research should be directed at helping academia study emerging economies in order to encourage growth and assist small traders both at national and international levels" $\{20\}$.

\section{BuSiness SCHOOls As Change Agents}

There are a number of elements that lead to long - term success of Business Schools within their broader programmes, community partners, and faculty champions, MBA and undergraduate alumni and those that participate in various programmes within Business Schools. Other issues are infrastructure, administrative champions, learning space, funding and so on. This is precisely what The Regent Business School is continually addressing. It is not the aim of addressing these issues in this paper but, to concentrate on one important aspect Business School Alumni. Sengupta and Ranachan (2015) state in this regard that "Business Schools must utilize a broad and diverse group of alumni as programme coaches" $\{23\}$ The Regent Business Schools Entrepreneurial Centre will therefore, provide its alumni with the opportunity to apply the knowledge and skills developed through their business classes and experience to small businesses, and in so doing students will be supplied with a state of the art infrastructure. In this regard Masten, (1993); Marbley, (2006) state that "the integral value of mentorship has been established in general entrepreneurship literature in both online, distance and offline environments $\{24\}$. The new Entrepreneurial Centre at Regent Business School will explore these options in its implementation processes to empower participants that will engage the modalities and processes involved in small business entrepreneurship programmes.

\section{LIMITS AND POSSIBILITIES}

"Theoretical advances do not just occur through conceptual refinement but also develop from problems and difficulties encountered in historical work and political practice" $\{6\}$. It must therefore, be appreciated that popular history is not the same as "public history, the kind put out by, for example, the South African Broadcasting Corporation $(\mathrm{SABC})$, the press and other sources that dominate the media in South Africa. "Popular history is therefore, standards of interpretation, simply the social history of the past, created for its own sake, or to serve the ends of those in power, as was the case under apartheid $\{4\}$. This is also being increasingly entrenched by the African National Congress government (ANC), post 1994. There has been no real change in this direction and, the apartheid status quo has been maintained by the democratic government and the predominantly White businesses and large corporations. Unlike public history, popular history is alternative history and has a radical aim, and therefore, by definition cannot be wholly co - opted by the dominant media. On the other hand, it must be noted "that popular history is located in the present, seeks to examine the conditions on which contemporary dilemmas and struggles rest, and to trace the origins of our particular capitalist world as far back as it is necessary to go. The Regent Business School having crystallized, and analysed the distinct problematic, in terms of the lack of entrepreneurship development and small business starter initiatives in the country, is therefore, desirous to practically address this dilemma by providing entrepreneurship training, development and business opportunity for local South Africans. The proposed new Regent Business School Entrepreneurship Centre will attempt to harness other local and national organizations, foreign embassies, private businesses, the KwaZulu - Natal provincial government and other interested business parties and municipalities to support this important development and 
initiative, in order to enhance and promote the business acumen of local entrepreneurs looking for business opportunities hitherto not provided to them by successive governments and the private sector, be it in both the pre and post democratic era.

According to Callinicos $\{5\}$ "One might argue that in locating history so firmly in the present, there is a danger of viewing it teleologically, or deterministically. But there is no reason why we should look at the past simply as a precursor of the moment we find ourselves in now, or simply raid the past for useful confirmations." In other words when we analyse the words of Callinicos, he is simply stating that we should not be backward looking, romanticising, for example, the pre - colonial past in an attempt to build up a national consciousness. The academics at Regent Business School, some of them at least have contributed to the overthrow of the oppressive apartheid system and, some of them were even jailed for their convictions by the apartheid state. Indeed they therefore, like Regent Business School see the present as an on - going historical process, and within this process is attempting to contribute to rectify some of the pitfalls of past history, and thereby, contribute to the development of South Africa in its own right. For example, to adapt our thinking at Regent Business School, we might seek to gain an understanding of contemporary resistance to Black education by some quarters of the historic privileged classes of South Africa and, the failure of government to provide free education and access to both basic and higher education, over the last 21 years of freedom and democracy. Therefore, our attempt is to contribute to both education and training incorporating the importance of entrepreneurship and development to the 'left behind' and marginalized citizens of our country, in order to stimulate the economy and, to above all enhance the capabilities of those that want to enter the small business sector. Nothing more and nothing less is the aim of the Regent Business School. To do all of this, one would have to pose a series of questions about the past, and examine how the process of events has led to links between smaller groupings and the larger oppositional movements, and how this has shaped the forms of resistance today, which in turn must lead to future developments. As Herbert Gutman $\{7\}$ states in this regard "Things that people assumed were normal in their lives, like television or racism, are seen to have a beginning, middle and sometimes an end. When people came into contact with that perspective, they were, and are better able to think analytically about the structures that impinge upon them." This is precisely the aim of our endeavour through the proposed new Entrepreneurial Centre.

The Regent Entrepreneurial Centre, with the aid of people in the classes or community concerned, will in terms of the relations of class, race and gender attempt to understand the workings of the class or community to enhance training and, the entrepreneurial spirit, that is so sorely lacking among the Black population, the poor White communities, Coloureds, Indians and particularly women of the country. It is obvious therefore, that popular history "must examine the origins of present - day struggles" $\{8\}$ and therefore, we are at Regent Business School, attempting to translate people's experiences, the experiences of the masses, and the part they play in both maintaining and challenging the system. In this regard Bozzoli adds that "no short cut assumptions can be made, every concept in business or any other field must be spelt out, every word consciously chosen for its clarity of meaning, every event illustrated and the sequence of presentation carefully thought out" $\{10\}$. This would be the aim of the new Regent Business Entrepreneurial Centre. There would be no shortcuts to the development, teaching and training of aspirant individual business persons and of groups and organizations. In South Africa due to apartheid and the lack lustre performance of the democratic government post 1994, most people have been deprived of adequate formal training in the basic skills of literacy and numeracy. Theoretical skills in our country are mostly in the hands of formally trained intellectuals. Clearly there is a social division of intellectual labour, the knowledge and skills which are needed to record and situate people's experiences are dominated by the former bourgeois institutions and traditional White dominated universities of higher education and, therefore, we in South Africa produce and replicate a White and rising Black middle class culture. It is these people that have the resources and the time to impart theoretical meaning to communities and the working class, without understanding their objective realities, experiences, needs and culture. This is the downside of fostering the required business skills to those that have been historically deprived. Radical scholars and academics are in the same position, so are radical Blacks in the academic environment of post - apartheid South Africa, "because their culture is rendered invisible by the fact that, they are addressing their peers, and their accountability is to their peers, and to their institution which pays them" $\{8\}$. We at Regent Business School through our academic programmes and the proposed new Entrepreneurial Centre must challenge these notions in order to widen and enrich orthodox notions of scholastic excellence in South Africa.

According to Green "without some accountability to working class institutions or audiences, academic socialists can indulge in the 'complacent disconnectedness' that characterizes university teaching and scholarly publishing. It must be rooted in worker education" $\{9\}$. This leads our discussion directly, as to how to make resources available and to 
create the links, is related to having a working relationship with a community or organization. This has been sorely lacking in South Africa post 1994 and, has reinforced apartheid ideology by negating the requirements of the historically disadvantaged and thus maintaining the status quo. Without government resources and private sector intervention, not much can be achieved in the empowerment of Black small businesses and traders in South Africa, in terms of monetary inputs, facilities and infrastructure, including training at all levels of business, promoting small business traders or providing job opportunities to them, in order to gain experience and, then set out on their own. Nothing meaningful or tangible has been done by corporates and the private sector to empower and train small businesses and, informal traders to emerge as entrepreneurs. This has been the reality in democratic South Africa, post 1994 and, has to be reversed urgently. As academics, we have a dual allegiance, firstly, to the institution and, secondly to the outside audience. This is precisely what Regent Business School calls for, emphasising the latter within the proposed new Entrepreneurial Centre. In this regard, we are committed to learn and to listen to very disparate groups of people and attempt to understand their value system and their consciousness. We must therefore, try not to make errors of judgement in terms of our relations with those who will interact with us and the new Entrepreneurial Centre.

The concept of the 'bound' or 'unbound' intellectual according to Bozzoli (1987) and Ari Sitas $(1984 ; 1986)$ who state that "intellectual is an important issue to confront because he has to be directly accountable to a specific organization, has the advantage of being in a position to explore uncomfortable avenues, not hitherto considered or welcomed by a particular audience because, one of the contradictions in writing for the people' or even 'the workers' in South Africa is not acceptable to the establishment and to corporates" $\{8 ; 10\}$. But even those who write on behalf of workers specifically have complexities to consider; for in South Africa, the working class is starkly divided post 1994 and, there is much manipulation and interference by the government with regards the affairs of the labour unions, which dilutes the aspirations and rights of the working class and, stymies their emergence in many directions to prosper and break into the economy in a coordinated manner. Thus, South Africa, post 1994 and, in a country coming from the throes of apartheid ideology must be in a position to create a balance between these conflicting demands. Thus, there are differing interpretations of our post - apartheid society, and therefore, affects drastically methodology and approach in respect of a host of issues that confront South Africa. For example, there is uncertainty about the nature of our audience because each of the race groups has their own interpretations of issues, be they Black Africans, Whites, Coloureds or Indians. It is obvious that that our colonial heritage has emphasized ethnic and racial differences, with class cleavages distorted by rapid development of neoliberal policies of the present government and, intertwined with vulgar capitalism perpetuated by the government, the ruling elite and its partners both White, and Black.

The concept of the people is dangled in rhetoric but is problematic to these privileged groups. In this regard Bozzoli $\{10\}$ further points out that "South Africa is a deeply divided society because on the one hand we are faced with a fraction of workers on the retreat, those White workers - Britons, Jews and Afrikaners, who a mere 21 years ago were highly skilled have now become deskilled." They were protected by apartheid legislation to the detriment of Blacks, which has caused an extreme lack of skills in all directions of the economy and, has hindered the emergence of Blacks entering the business arena and, engaging the business environment successfully after 21 years of democracy and freedom.

Bozzoli $\{10\}$ points out that "it would be naïve to doubt the indoctrinating and manipulating capacities of South Africa's ruling classes, the logic of reform requires set of interpretations which are capable of appealing rather than dictating to the population and the new strata of White people." Businessmen for example cry out at the failure of dominant ideologies and, in spite of this consolidate their capitalist agenda at the expensive of the masses. The benefits of free enterprise in South Africa is not understood by the average worker and indeed more so by small traders and, therefore, renders them for the picking to socialism and ideologies as propounded by the new political party the Economic Freedom Fighters (EFF) with a misguided interpretation of socialism. This is most dangerous and the ruling party fears the inroads being made by the EFF. The ideological ferment of our times in democratic South Africa should therefore, be a wakeup call to the ruling ANC government, to intervene decisively to reverse the many situations that it has created, which is having a negative effect on the country and, could in the near future spell disaster for the economy but, above all stoke violent protests and civil unrest.

Much more research in this direction is required in order to get a more comprehensive insight to our society. It thus requires worker and people education coupled with small business training for locals. This is so vital because Aljazeera News reported on the $6^{\text {th }}$ of February, 2015 that "in Thailand 96 percent of businesses are run by small businesses, although owned by 10 families and, these small businesses are the backbone of this emerging economy" $\{11\}$. South Africa needs to take a leaf out of the Thailand experience and empower small businesses in South 
Africa to deal with a declining economy, violence and unemployment, with increasing poverty and rising inequality. To this end, the Regent Business Schools Entrepreneurial Centre attempts to make inroads in this direction in some small measure and, therefore, the government must support the Centre with some defined monetary inputs, resources, bursaries for entrepreneurial study, and the selection of small business entrepreneurs that could be trained in business, at this centre. The government needs to mobilize in its own interests, if it wants to survive and, in order to address the declining economy and, deal with the very high unemployment rate in the country. The government has to understand that the strand of popular opposition is making in roads and threatens its very survival. The question is who should lead this struggle, the workers or a popular alliance? The answer to these issues lies in the all-embracing reality that, transformation be redefined by the South African government, that it must be in a position to deal with the massive corruption that has engulfed the country, take steps against an inept and unproductive bureaucracy, get rid of political patronage, given the inefficiencies within some of its public enterprises, seriously consider partial privatization options, downsize the public service drastically, level the playing fields by cutting public service salaries, deal decisively with unemployment, inequality and poverty. It has to address a myriad of problematic issues and, stimulate the economy by supporting small business entrepreneurs. All these possibilities are within ourselves as South Africans because we need to take more control of our lives.

\section{ENTREPRENEURSHIP FOR PURPOSES OF A LOCAL RENAISSANCE}

According to the Premier of the KwaZulu - Natal province, (2014), "Entrepreneurship is the key to local renaissance and the idea of government's empowerment initiatives is to assist Small Medium and Micro Enterprises (SMME's) to start up, but the onus is on them to become independent and self - supporting" $\{17\}$. South Africa and the province of KwaZulu - Natal recently launched the Dube Trade Port as an economic zone, in the Port City of Durban. This initiative was long overdue because African expansion is a unique project. It is a renaissance from below. In reality the Dube Port is the largest harbour in Africa. It is integral to the development corridors through Southern Africa and to the rest of the continent. Mchunu (2014) adds that "The global economic meltdown a few tears ago, which saw the major European economies sink shows that, South Africa has moved from being a bit player in the global economic sphere to being a player to be reckoned with. Our membership in Brics announced our arrival in the major leagues of the global economic playing fields. A paradigm shift in the global economic environment is now evident. Africa is touted as the new investment destination. And therefore this province can be used as the gateway to penetrate the continent and other world destinations, and for the benefit of other provinces within the region." $\{17\}$. This brings us to the question as to who should drive the exploitation of these comparative advantages. It is the entrepreneurs both large and small. It therefore triggers a further question - Do we have entrepreneurs that can and are ready to utilize these advantages. The Regent Business School has made an investment in the form of its new Entrepreneurial Centre, in order to promote and train small entrepreneurs and, thus is most committed and interested to take the plunge into business training and development, as outlined by the Premier of KwaZulu - Natal. It is hoped that the Premier will support and take a quantum leap in assisting the Regent Business School to empower locals in this state of the art facility, to train and develop the inhabitants of the province, especially the youth. There is thus major room to action improvement by fostering a culture of entrepreneurship development. It has to be stated that although the Premier identifies this gap, thus far it has not yielded the desired quality of entrepreneurs, after nearly 21 years of freedom and democracy. It is therefore, Regent Business Schools desire to contribute to a new trajectory of business emergence, small trader involvement, the consolidation of small businesses by means of appropriate training in this direction.

Sadly, South Africa's entrepreneurial activity is improving, but still lags behind other emerging markets. Mchunu (2014) $\{17\}$ states that " according to a study in 2010 undertaken by South Africa's First National Bank, entrepreneurial activity in the country is measured by TEA (Total Entrepreneurial Activity) or "early stage entrepreneurial activity" index stood at 7.8 percent in 2008, greater than 2006 (5 percent), but still lower than India - Brazil (11. 5 and -12 percent), Colombia (24. 5 percent), Mexico (13. 1 percent) and even the US (10.8 percent). TEA measures entrepreneurial activity by looking at the percentage of the active population, people between 25 and 64, who are entrepreneurs in any given country." $\{17\}$. This is what we in South Africa and the province of KwaZulu - Natal have to address and address urgently, if we are to compete and grow the economy of our country and the region. We need to do something drastic and do it now. We need to create entrepreneurs. The idea that encompasses empowerment initiatives is that they assist entrepreneurs as they start out and, after a while entrepreneurs are expected to graduate from these programmes to stand on their own. It is precisely what the Entrepreneurial Centre at Regent Business School aims to achieve, but it cannot do it on its own and, we hope that the Premier and his bureaucracy will support Regent and take this important project and initiative forward. 
The Premier (2014) $\{17\}$ went on to state that "in order to create conditions for entrepreneurs to thrive, it has become clear that the participation of academia, established business and funding agencies cannot be overemphasized." Heeding this clarion call, the Regent Business School has rallied and, is now giving meaning to entrepreneurship and the emergence of entrepreneurial training in the Port City of Durban. The Premier made a resounding call that all stakeholders partner with them to build new entrepreneurs. To determine how entrepreneurship responds to the challenges that the future holds. To this end Regent Business School has actioned the Premiers call and vision and, it is hoped that, the Premier will personally support Regent Business School's Entrepreneurial Centre to action his vision and the vision of the Province, Region and the country. The envisaged strategies of the Province and the strategies of the Regent Business School (Discussed in this paper) sets out critical markers for employment creation and growth, for entrepreneurial development, training of small traders, start up packages for own small businesses for purposes of growth, dealing with unemployment, and identifies where viable changes in the structure and character of production can generate a more inclusive and greener economy. When shall we begin? The Regent Business School can contribute significantly to the renaissance that, the Kwa - Zulu Natal Premier envisages and so adequately articulated by him.

\section{DEVELOPMENT MORE THAN ECONOMICS}

It is important to very briefly unpack some issues pertinent to development discourse as it pertains to the importance of the development discourse within developing countries. This was exemplified and articulated for many years as a widespread tendency to reduce the problems of developing countries to economic problems. "Many of the original theories of development were first and foremost theories of economic growth and economic transformation. There was a belief that the social dimension to 'Third World' development was not important and, by the same token did not initially embrace the importance of political and cultural considerations" $\{12\}$. It is obvious therefore, that development theories in their original formulation did not raise questions about the extent to which, political and cultural factors influenced economic development. As a rule the development discourse in its initial and rudimentary stages of development and applicability, did not concentrate in describing what actually happened to political and cultural life, when developing countries went through economic crisis or experienced rapid economic growth. In this regard, these development theories formulated by the West and premised on Eurocentric thinking in the main, in terms of their initial formulations were weak in terms of economic analysis but were extensively used by the International Monetary Fund (IMF), the World Bank (WB) and other organizations and, this was a great drawback to development in developing countries which, were used and implemented, with ungrounded assumptions relating to the 'Third World.' Thus developing countries were specifically told not to factor the variables of politics and culture into their equation of development. This led to the impoverishment of 'Third World' countries and their economies. It led to structural adjustment programmes of the economies of the developing countries by the IMF and the WB, which led to devastating consequences in terms of the schedules of high interest rates, downsizing the public services, realignment of development policies as outlined by these institutions and, above all gave rise to a predatory elite in the developing countries, which put paid to development and the advancement of the majority of populations. The other consequence of IMF and WB intervention led to countries inabilities to advance the business development agendas of their people. Training was therefore together with skills development, not an imperative of "Third World governments and, this caused tremendous upheaval, marginalized the poor and devastated the economies of the 'Third World.' These policies were carried into the $21^{\text {st }}$ century and are consolidated, streamlined and refined even today, with the aid of the ruling elite in many African countries. We therefore, find that, all of this have put paid to the emergence of development imperatives and has stymied business and small business development in Africa as a whole. We posit therefore, that, foreign Direct Investment (FDI) and the concept of Africa Rising for all intents and purposes is a myth and a mirage of the distant future as corruption, the rising corrupt elites and dictatorial "Third World" governments are in reality out of tune with the imperatives of sustainable and coordinated development programmes that are much needed for the advancement of their poor populations," according to Karodia and Soni (2014), $\{15\}$.

The discourse of development theories since their inception has been most complex and these complexities are not the concern of this paper and requires in depth discussion and analysis in research methodology that, must be the purview of development theorists. However, this brief discussion was important in order to situate the subject matter, in order to better understand the development agenda and the business imperatives of developing countries. Some of the guiding questions that form the basis for discussion according to John Martinussen (2004) \{11\} are summarized as follows: 
$>$ "How have the developing countries changed according to the theories? What has happened, and what is about to happen in these countries internally, and in their relationship to the rest of the world and the international system, again according to the theories.

> What conditions are particularly crucial for the kinds of changes that may be called 'development'? What type of development concept is contained in each of the theories?

> What explanations do the theories offer for development, maldevelopment or underdevelopment and stagnation? In addition to economic factors, do they include also political, social, cultural and ecological factors and, if so, how?

$>$ How do the theories take into consideration internal differentiation within individual societies?

$>$ What development strategies are suggested in the various theories? Do the suggestions take into account the economic, political, and cultural realities? Do they incorporate environmental, security and emerging business problems and other concerns, and if so, how"? $\{11\}$.

$>$ In other words development theory must seek to answer questions such as the following:

$>$ "How can chosen specified development objectives be promoted?

> What conditions will possibly obstruct, delay or detract progress towards the objectives?

$>$ What causal relationships and laws of motion apply to the societal change processes?

What actors play dominant roles, and what interests do they have?

$>$ How do the changes affect various social groups and various geographical regions? $\{11\}$.

The Regent Business School in crystalizing its efforts in the promotion of its new Entrepreneurial Centre has noted and taken into cognizance that the above questions are not value - neutral, but that they set the stage for greater analysis, unlike the development concept, in terms of how social reality and its related concerns must be actually structured, as opposed to how it ought to be structured. It has also identified the actual conditions that must be considered in terms of historical experiences. It is against this background that we aim to understand and project the aims and objectives of the Regent Entrepreneurial Centre and, in so doing play a small and significant role, in the much desired role of business for small new entrants and small business traders, in the development of South Africa, by contributing to economic growth and towards people that were denied and, are still being denied access to business opportunities and possibilities.

The aim of the paper is not to go into detail about development theories and economics, but the brief expose, of this important subject was aimed at exposing the reader, to some important issues that permeate the development discourse, its proper conceptualization, their control by the IMF, the WB and implementation by mostly corrupt developing country governments and, their bureaucracies and the elites of these countries, and to the detriment to development of the masses and coordinated intervention, for purposes of business development, economic growth and the advancement of the poor, that make up the masses of developing countries.

The theoretical expose undertaken thus allows us to now put forward the aims and objectives of the Regent Business Schools proposed new Entrepreneurial Centre, which for all intents and purposes must have a development agenda, in order to enhance business and particularly small business development. The discussion hereunder captures the nuances involved in this regard.

It was imperative and necessary to introduce the subject matter in some detail in this first part of the paper. However, the analysis has not been all encompassing but sets the tone for further analysis of important issues and variables. These issues and variables address issues that must be taken into consideration, in terms of the lives of the poor, dispossessed and marginalized in South Africa. In respect to the existence of capitalist democracy in developing countries, it is more likely that voices of the poor classes will be heard in South Africa. In this regard Bozzoli (1987) $\{10\}$ states that "Right - wing governments may attempt to block the development of alternative approaches through control of funding and a host of other reasons that permeate civil society." It is a question of hegemony, were dominant ideologies, that seek to capture the hearts and minds of ordinary South Africans, which often provides a distorted image of our past and present and there exists a great need to counter them. The rooted modalities of teaching in both our basic and higher education departments in terms of approaches must be overhauled. The Christian National focus of apartheid that permeated our education in South Africa probably enforces views that are out of tune with the transformation agenda of the state. There is much cynicism among Blacks with regards business, history, social discourse, government and the like in the new democratic South Africa. Thus the state itself seeks new ideological forms for purposes of remoulding its hegemony. In the new South Africa 
both Whites and Blacks are being subjected to new ideological overtures by state and capital. This is most dangerous because the agenda of capital and that of the state are increasingly coming together in the formation of neoliberal policies that work against the people crying out for equal opportunity in all aspects of South African life, post 1994. Therefore the legitimacy of reform in a democratic South Africa is increasingly becoming questionable.

The African National Congress, trade unionists, community organizations and large - scale movements, given the unfolding situation in South Africa after 21 years of democracy, they all seek to present new models of development to appeal to popular audiences, and therefore, people's education and alternative education models and business strategies will be in demand. Ordinary people in terms of their support to the system, seek clarity from the government and the opposition in these difficult and bewildering times in South Africa. Factors such as these require urgency, vitality and a sincere commitment by those that serve the South African population. "There has to be therefore, a challenging revision of the common past of all South Africans, regardless of their present day affiliations and to free ourselves from narrow political concerns because, we still find in a democratic South Africa, to challenge the ongoing inequities that we face because, trade unionists might want class to be the fundamental category within which all explanation should fit, and the African National Congress want their agenda to prevail" $\{12\}$. A whole range of ideological assumptions underlies the many perceptions of even the simplest social interpretations. Many of these assumptions have their roots in the cultural forces which have shaped and controlled South African thinking of Black South Africans. Our attempt to open the Regent Business School's Entrepreneurial Centre, given our history, the dominance of Eurocentric and Western education, the dominance and control of business by Whites within corporates, which is exemplified by more than 70 percent of human resources, management and executive positions held by them and, therefore, our aim is to demystify this myth that has held Black business emergence to ransom. Our aim simply put is to reflect upon the salient and important issues such as society, the state and market on the one hand and to deal with class, community and conflict. This will thus allow the school to broaden entrepreneurial teaching, its practical underpinnings and application to a historical audience of people that were and are still marginalized. This would allow us to define and charter a course of small business intervention and, develop strategies that would empower people to take their own destiny into their hands by emerging with the necessary small business skills that the country requires now and, more than ever before.

\section{Regent Business Schools Strategic Plan For The Centre For EntrepreneurshiP}

Given the discussion undertaken above which opens up a wider debate and situated the issues that confront South Africa pre and post democracy, there were two critical publications commissioned by the institution. These were Social Entrepreneurship and Social Innovation: Reclaiming Development in South Africa and Entrepreneurship: Re - imagining a New Campus Habitus, and given that entrepreneurship is becoming increasingly important throughout the world, and that there is a strong correlation between national economic growth and the level of entrepreneurial activity, Regent Business School intends to launch a Centre for Entrepreneurship in 2016 and institutionalize Entrepreneurship Education into its core curriculum. The Centre will support a culture of entrepreneurship throughout the institution and the local economy and provide access to entrepreneurial resource networks to help businesses get started and grow.

The foregoing discussion is drawn from the strategic plan of the Regent Business Schools Centre for Entrepreneurship which was draw up by its subcommittee consisting of Professors Soni and Karodia, Zeyn Jadwat, Ahmed Shaikh and Ridwan Asvat (2015) \{13\}.

The document outlines that "Entrepreneurship education contributes to promoting life skills for individuals, expanding their experiences, developing readiness for work, enhancing creativity, innovation and productivity, and supporting the trend towards self - employment in order to reduce the unemployment rate among youth in South Africa. Entrepreneurship also contributes towards the empowerment of students and encourages self - development, takes initiatives, bears responsibility and risks, and thus creates a generation of students who are productive and creative and turn their entrepreneurial ideas into productive projects, making them change agents. Ultimately, entrepreneurship contributes not only to the development of the national economy, but also to life skills for individuals, and prepares them for the labour market.

The integration of entrepreneurship education into the core curriculum of Regent Business School will add great value to the whole process of teaching and learning at the institution and its long term goals. It must become the DNA of the School. This initiative will increase the students' ability to anticipate and respond to societal changes and encourage them to develop and make initiatives, and deal with risks successfully. The Centre and the School will ensure that it is not business as usual at the institution. It will be guided by its entrepreneurial habitus and empower its students to be socially responsible. It will aim to be an internationally recognized institution of 


\section{American Research Journal of Business and Management, Volume 1, Issue2, 2015 ISSN 2379-1047}

excellence in educating, researching, supporting and developing social entrepreneurial projects and innovation within the economy and promoting scholarship in entrepreneurship. It will deliver outcomes that form part of an increase in social entrepreneurial innovations and social enterprises aimed at the attainment of the National Development Plan and goals, and the eradication of poverty and social challenges facing South Africa's young democracy and the continent, at large. It will also provide unique and flexible value - added solutions that are relevant to local needs and adaptable to the local context through synergy of efforts by Regent Business School, the local, provincial and national state, the private sector and other local for - profit and non - profit agencies. Finally the Centre will enable national and international conversations through national and international leadership seminars, workshops and conferences and increase opportunities for entrepreneurial learning and activity.

\section{STRATEgic LONG TERM OBJECTIVES}

Besides being a hub for excellence in education, research and outreach in entrepreneurship, the Centre of Entrepreneurship at the Regent Business School will aspire to $\{13\}$ :

Ensure a rich and high quality programme of entrepreneurship education aimed at the development of greater achievement motivation, independent and innovative thought process and mastery of vocational skills;

Extend entrepreneurship education opportunities to the Ethekwini Municipality (Durban), the Province of KwaZulu - Natal and South Africa on a continuing education platform via workshops, consultancy and short certificate courses;

Develop and implement strategies and programmes, blurring the boundaries between business, government and non - profits, adopting and adapting the tools and knowledge from all sectors to improve performance;

Through training and education provide social entrepreneurs / enterprises with access to the resources necessary to maximize, sustain and scale social impact;

> Promote social entrepreneurship and social enterprise development by holding colloquiums, seminars, workshops and symposia;

$>$ Network with similar institutions or centres globally, enter into joint ventures with such institutions and to source best practices in social entrepreneurship and social enterprises development that could be introduced or replicated in the relevant environments or to similar challenges;

$>$ Be a bridge between university, state, and local communities;

Integrate resources of Regent Business School, the state, and local communities to contribute to the economic growth of the country;

> Provide one - on - one technical assistance in business development and management to local entrepreneurs;

Provide education and training to local entrepreneurs;

Maximize Regent Business School brand equity;

Improve core competency in developing youth entrepreneurship programmes;

> Build relationships and generate opportunities with the local, regional and national entrepreneurial community;

Advance commercialization and other forms of utilization of leading - edge entrepreneurial research;

$>$ Promote innovation and entrepreneurship that spans a wide range of needs, including social, political, health, environmental and technological;

$>$ Increase the number of students who participate in entrepreneurial work opportunities as part of experiential learning;

Support entrepreneurial activities leading to start - up company creation;

Facilitate student, faculty and staff entrepreneurship in a broad range of fields, including social entrepreneurship (not for profit);

$>$ Encourage research into entrepreneurship;

$>$ Develop learning opportunities to address entrepreneurship in relevant courses; 
> Provide a repository (including a webpage) for all entrepreneurship activities;

Leverage the entrepreneurial skills of alumni. $\{13\}$.

$>$ In achieving some of the issues outlined above, the SABC News on 9 February, 2015 reported that "South Africa has to promote small businesses and in this regard the regulatory framework of small business engagement in the country must be revised, in order that it facilitates more rapid entry into business by small owners and traders. The regulations must afford appropriate concessions to new entrants and those that are currently engaged with small businesses" $\{16\}$. In the absence of revised regulatory frameworks and government concessions to small businesses, not much can be achieved in this direction.

The Regent Business School has also identified short term goals for 2015 and has identified an array of strategic partners. Thus the Centre for Entrepreneurship will work in collaboration with various other agencies to achieve the "growth path" envisaged in the governments new Development Plan for South Africa. The offering of strategies and programmes, blurring the boundaries between business, government and non - profit organization, adopting and adapting the tools and knowledge from all sectors and disciplines to improve performance, develop new approaches and attract more resources to the economy will be of utmost importance to the new Centre for Entrepreneurship at Regent Business School. Thus, the proposed new embedded entrepreneurship curriculum and the new Centre will use the new social value - driven concept of entrepreneurship as its habitus for outreach in basic needs development. $\{13\}$.

\section{Private Providers Can Widen ACCeSS To Higher EduCation In SOUTH Africa: A FERTILE IDEA WHO'S TIMER HAS COME}

Shaikh, Karodia, David and Soni (2015) $\{14\}$ indicate that "an academic revolution has taken place in higher education in the past half - century marked by transformations unprecedented in scope and diversity. Globally, public higher education is in the throes of a major crisis. This crisis in South Africa revolves around the question of access in higher education and therefore, public - private partnerships in the provisioning of higher education is fundamentally important to South Africa. It is therefore time to confront this inconvenient truth. We need to boldly traverse new terrains and public - private partnerships in the provisioning of access to an incommodious problem. To this end the Regent Business School as a private higher education provider and also an undergraduate study provide, together with its proposed new Entrepreneurial Centre, aims to assist the process of access to higher education in South Africa. (Refer to the full article titled: Private Providers Can Widen Access to Higher Education in South Africa: A Fertile Idea Whose Time has Come. (Press release January 2015 and in BizCommunity and MBA.co.za, South Africa). $\{14\}$.

\section{When Public Higher Education's Doors Are Bolted: Private Higher Education InSTITUTIONS Must Be CONSIDERED By Goverment As A Feasible OPTION To Alleviate THE CRISIS}

The funding of students to higher education in South Africa is in dire straits and therefore the doors of higher education in South Africa are bolted or closed for thousands of students who derive from poor families, yearning for education. The National Student Financial Aid Scheme (NSFAS) has said according to Bongani Nkosi (2015:11) "it has run out of funds and many students run the risk of dropping out." A disaster in the making and the department of higher education just does not have a plan to deal with the situation \{26\}. Nico Cloete (In Nkosi, 2015) Director of the Centre for Higher Education Transformation states that "The real tragedy was that university dropouts would join about three million youth who are not in education, employment or training and this is where the door of learning is bolted because about 800000 of these 18 to 24 - year - olds have a matriculation certificate. Although the government has allocated increased funds to higher education, these have not kept pace with university fees. Tuition fees have risen R7.8billion in 2000 to R15.5billion in 2012 and students over the twelve year period have has to find R7. 7billion more" $\{26\}$. NSFAS funds have tripled but they cannot fund all students. Most parents who earn a combined income of R150 000 cannot afford to send more than one child to university. Students have said that they study on empty stomachs and many parents cannot afford re - sponsoring their children after the first year of study. Many do not have textbooks. It has to make sense to the government to increase funding and by the same token support private higher education colleges and institutions to cater for dropouts and other students at much lower university and tuition fees. It is obvious therefore, that Entrepreneurial Centres like the one Regent Business School has envisaged and is investing in are vehicles that require government and private sector support without any let or hindrance for purposes of developing the economic potential of those South Africans yearning to enter the precincts of business, in order to grow the economy. What better way is there, but to invest in the entrepreneurial 
American Research Journal of Business and Management, Volume 1, Issue2, 2015

ISSN 2379-1047

development of the youth and those desirous of entering and engaging through skills development the economy of the country?

By comparison the South African state spends less on higher education than Ghana, India and Brazil, when compared as a percentage of GDP. This is reflected in Table 1 below: $\{26\}$.

Table1. The state spends less on higher education than Ghana, India or Brazil

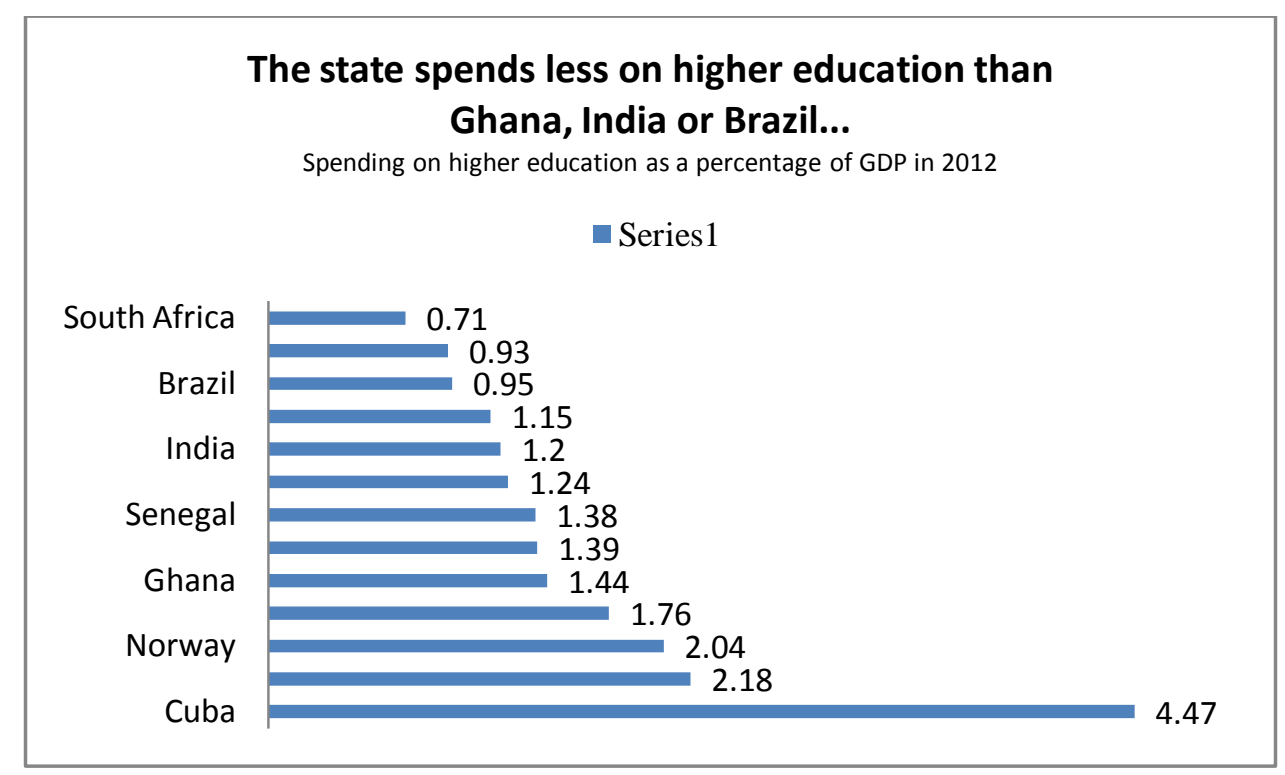

Please note that the stream refers to any income other than fees or subsidies grants, donations or entrepreneurial projects.

\section{SOURCE: MAIL AND GUARDIAN, 2015 FEBRUARY 26 AND ChARLES ShEPPARD (OECD, DHET)}

The two graphs depicted below show the following as reflected in:

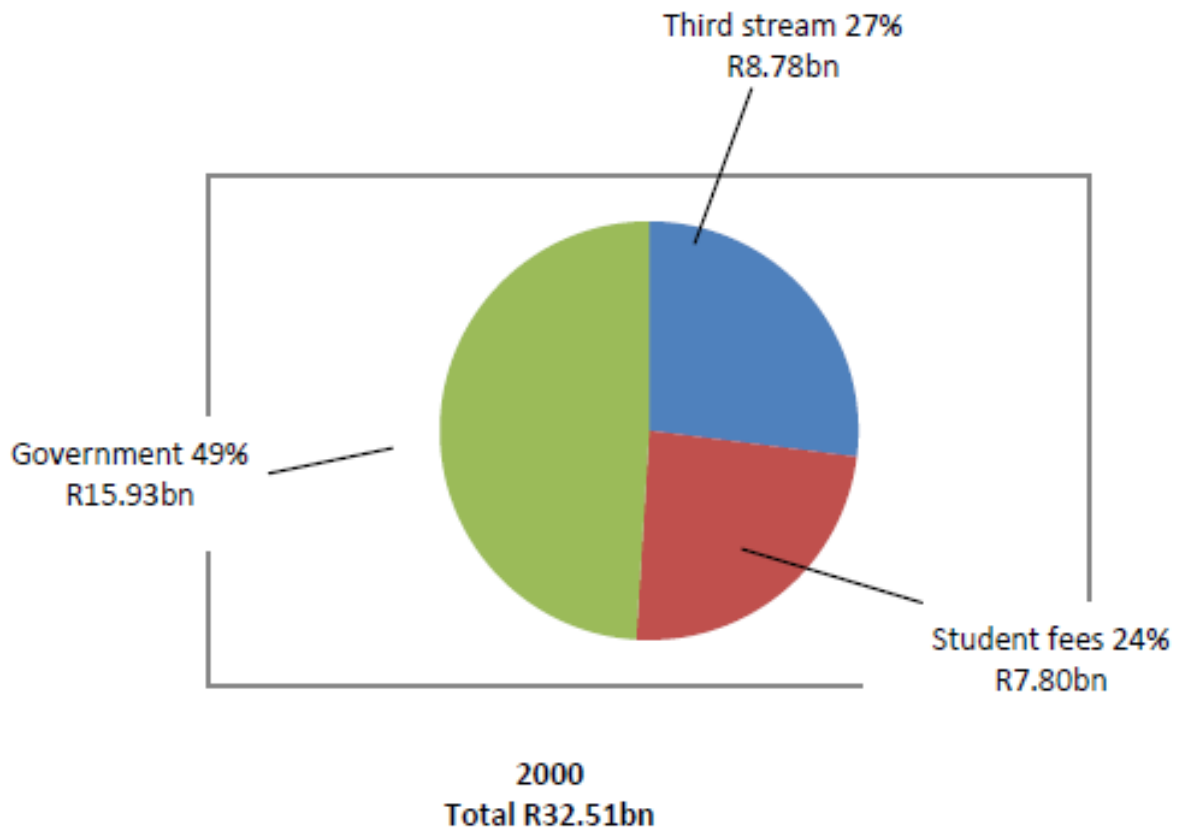

Graph1. The proportion of higher education income student fees has risen sharply 


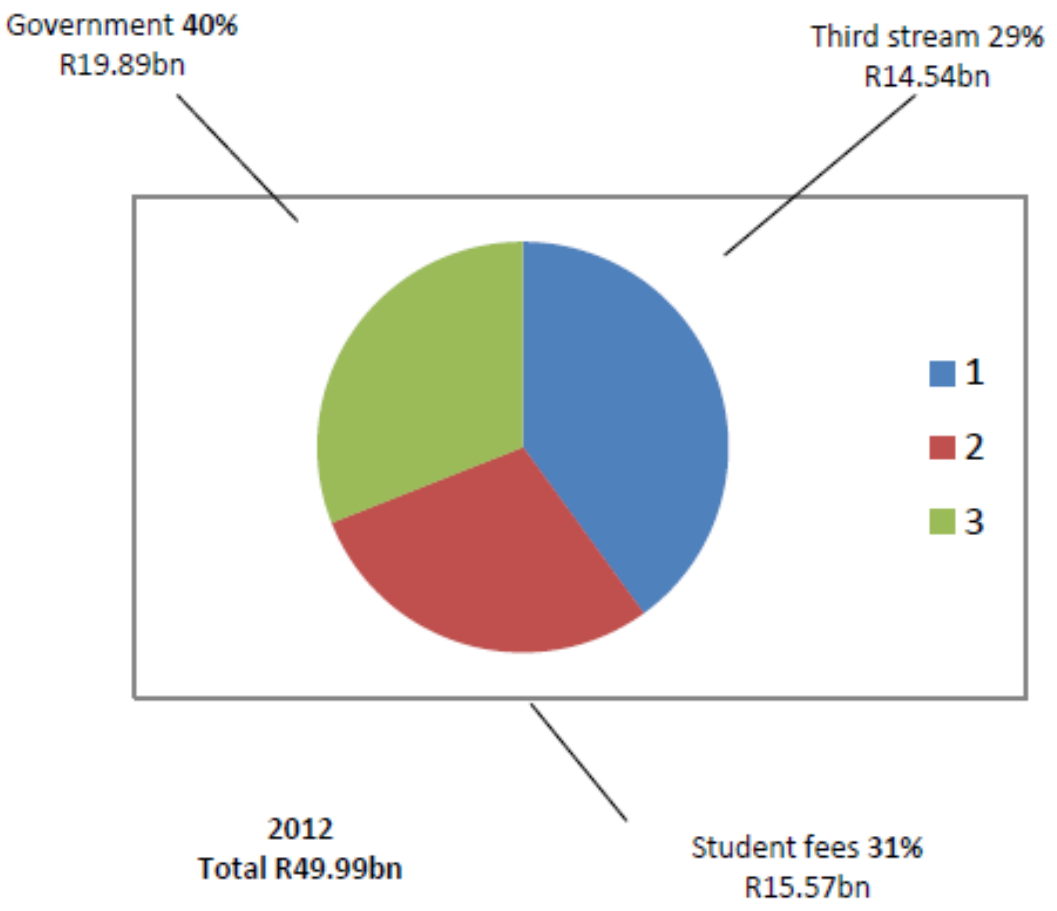

Graph2. Higher education income sources a percentage of total income in South Africa

\section{SOURCE: CHARLES SHEPPARD, 2015; OECD, DHET}

The graphs are self explanatory and the reader can analyze the problems that South African higher education has to confront. The government's contribution in monetary terms is not what it ought to be and is an indictment to 21 years of democracy. Such a situation adds to the problems of the so - called developmental state that the government is in pursuit of. It appears to be more lip service than a sustained and necessary intervention strategy in relationship to higher education transformation.

\section{THE VAST UNIVERSITY DIVIDE}

Formerly deprived institutions including the very few Black owned private higher educational distance education providers need enormous redress funds from all sectors of the South African economy, including government because the chickens have come home to roost. According to Jordan (2015: 37) "I came to understand this beautiful English idiom earlier this year, when those who came to roost were the late applicants to South Africa's historically advantaged universities, usually abbreviated as HAU's. The queuing of students at universities in South Africa year after year after the matriculation results are released is an ugly sight" $\{28\}$. This is exemplified by one university, the University of Johannesburg in 2015 which received 100000 applicants but could only absorb 30000 and the University of KwaZulu - Natal that could only take in 12000 students from the 90000 that applied. This is the situation across all South African universities and has to be addressed by government in the form of resources to the historically disadvantaged universities in the public domain and private higher education institutions. What really happens that applicants who are turned away from the historically advantaged universities then attempt to seek admission at the historically disadvantaged universities? These universities cannot absorb the high number of applicants and the government does not enter into a compact with private higher education institutions in a drive to assist and address this grave problem. Many are admitted into degree programmes and courses that they do not want to pursue. Academic standards are also compromised and there are high dropout rates that the country has to contend with. There has to be massive redress funding that must be made available. In this regard Jordan (2015) states that "the panacea for these formerly disadvantaged universities' severe distress is the financing of an enormous redress fund, comprising government, private and other financial resources" $\{28\}$. In this regard some of the disadvantaged private higher education institutions must also be supported.

It makes no sense to place these disadvantaged universities and some of the private institutions on the same financial terrain as the richest ones. Nothing has really changed over 21 years of democracy and the situation is worsening. Over and above these problems Jordan (2015) states that "you still see the same student demographics, the same 
staff complexion, the same physical infrastructure, the same resources generally, the same everything. This phenomenon has to be meaningfully addressed. It does not seem that there is political will to intervene $\{28\}$. Clear thinking is required by the Ministry of Higher Education to effect meaningful and necessary change. In this regard Jordan (2015) states that "South Africa needs an organic metamorphosis of higher education." In this regard he identifies the following intervention strategies:

A need for redistributive justice.

All universities must offer traditional qualifications.

$>$ Some degree programmes must be moved from the richer universities to the disadvantaged universities.

$>$ The problem of seasonal overcrowding will in some measure be dealt with if the above is actioned and in addition disadvantaged private higher education institutions must be supported.

$>$ Funds must follow functions and this must bring about even funding to disadvantaged universities and to some private higher education institutions based on a formula and within the ambit of defined modalities.

$>$ Demand always seeks supply and private higher educational institutions could in many ways and in defined programmes fill this necessary gap.

$>$ The private sector must come to the party in respect to funding.

$>$ The need for competent academics must become a priority.

$>$ It must provide for racial reconciliation.

> Perpetuating privilege must be broken and turning away a majority of black students from the advantaged universities must also be dealt with" (Jordan (2015) \{28\}.

\section{Advocating For A PARADIGM SHIFT In ENTREPRENEURSHIP INNOVATION AND SMME DEVELOPMENT IN SOUTH AFRICA}

A focus on small, medium and micro - enterprises (SMME's) is internationally accepted and regarded as a sound imperative for economic development. Entrepreneurship according to Shaikh, Karodia, Joseph and Asvat (2015: 1) "is a precondition for any business because South Africa is an underperformer in this regard. It has just not met expectations and therefore it is imperative that getting South Africa's entrepreneurial culture right must be a fundamental priority" $\{27\}$. The creation or absorption of new technology through the medium of turnkey operations must become a vital component for companies to improve or maintain their competitive position in the market place. In this regard investment in new technologies must become an imperative because the development of new technologies is a crucial element of the competitive strategy of any enterprise, big or small, high - tech or low tech. The ongoing integration of domestic and international markets through continuing deregulation and liberalization of markets has enhanced competitive pressure for all firms, and especially increased the technological needs of small enterprises worldwide while also improving their access to new technologies and capital goods. Shaikh, Karodia, Joseph, and Asvat (2015: 2) point out that "the issues of social entrepreneurship and social innovation must be firmly embedded in the founding principles of the new centre. It must be undertaken within the context of the requirement to empower entrepreneurship for the greater good of communities rather than individuals. This approach is a significant departure from the traditional model of entrepreneurship adopted by many empowerment agencies and institutions, both in the public and private sectors internationally and locally" $\{27)$.

There is no doubt that the challenge for South Africa lies in the reality to develop innovative ways by which the required critical mass of skills can be developed quickly within a range of SME - oriented institutions and within SME's themselves. To assist the government in this country to develop this critical mass of skills, the Centre for Entrepreneurship at the Regent Business School will be working in partnership with various agencies both public and private, and will be seeking funding to commence a technology transfer capacity building programme in the SMME sector," $\{27\}$ according to Shaikh, Karodia, Joseph and Asvat (2015: 6). They further state that "to ensure that this capacity building effort reaches a larger group of entrepreneurs and SMME's through a "multiplier effect" the Centre of Entrepreneurship will adopt a "training for trainers" strategy in partnership with foreign agencies such as the National Small Industries Corporation (NSIC) of India" $\{27\}$. These trainers would then be expected to return to their respective communities and train SMME's through business and industry associations and relevant government organizations. The Centre for Entrepreneurship at Regent Business School would also provide the trainers with all the relevant training materials. Under this technology transfer capacity - building "training of 
trainers programme" participants will be imparted skills for the greater good of the country, its communities and its people.

The new entrepreneurship and small development paradigm which Regent Business School propounds is a significant departure from the traditional Western - based model. In the first instance, the new social entrepreneurship and social innovation paradigm insists that, the business venture should assist and contribute towards the overall empowerment of a collective rather than just an individual. In this way the new model of entrepreneurship contributes to the gainful employment and skills development of more than one person. Secondly, and perhaps more importantly the new model prioritises the mission and intrinsic value of social responsibility in a country that is attempting to emerge from the drastic and negative impact of apartheid ideology that, has dented the economy, skills development, destroyed human potential and created an inferiority complex in the minds of the majority of the nation's population. This has to be reversed in order to create a successful South Africa for purposes of developing the inherent potential of human beings and stabilizing the economy for peace and prosperity.

\section{CONClusion}

The paper undertook complex discussion and unpacked some issues that require immediate attention by the Ministry of Higher Education in South Africa together with government and other stakeholders. One of these stakeholders is the Regent Business School and its new Entrepreneurial Centre. It is hoped that the different thesis advanced in this paper on higher education and entrepreneurship and the role that the Regent Business School together with its new Entrepreneurial Centre could play in the development of South Africa must not be underestimated. Its investment into the Entrepreneurial Centre challenges the protagonists of higher education institutions, in the form of the elitism of the former historically advantaged White Universities in South Africa, who after 21 years of democracy still maintain the status quo, prevent access to Black students. We are confident that, if we get the support of government and other benevolent partners in our historic endeavour, the issues of equity, access and finance could be addressed in some important small measure. We are further confident that, we at Regent Business School will hold our own and, in time become one of the institutions as a vanguard in determining the outcomes of similar chronic exigencies in South Africa and the emerging economies of the world.

\section{REFERENCES}

[1] Marho (1983). Visions of History. The Mid - Atlantic Radical Historians' Association. Manchester. United Kingdom. Page 16.

[2] Martin Nicol (1987). In Class, Community and Conflict: South African Perspectives. (Belinda Bozzoli, Editor). Ravan Press. Johannesburg. Republic of South Africa.

[3] Martin Nicol (1987). In Class, Community and Conflict: South African Perspectives. (Belinda Bozzoli, Editor). Ravan Press. Johannesburg. Republic of South Africa.

[4] Budlender, D; Cooper, L; Hofmeyer; and Kaplan, D. (1985). Introductory Notes to the History Workshop. Industrial Psychology Department. University of Cape Town. Republic of South Africa.

[5] Luli Callinicos (1987). In Class, Community and Conflict: South African Perspectives. (Belinda Bozzoli, Editor). Ravan Press. Johannesburg. Republic of South Africa.

[6] Introduction to The Peoples Workbook (2009). Rural Understandings of History. University of Witwatersrand. History Project. Johannesburg. Republic of South Africa.

[7] Herbert Gutman (1983). In Philip Bonner: Introduction to presentation of Fosatu Worker News to History Workshop. University of Witwatersrand, Johannesburg. Republic of South Africa and in Bellinda Bozzoli Editor (1987). Ravan Press. Johannesburg. Republic of South Africa.

[8] Ari Sitas (1984 and 1986). "Culture and Production: The Contradictions of the Working Class in South Africa. History Workshop paper... Also published in Africa Perspectives. New Series Volume 1. No. 1 and 2. University of Witwatersrand. Johannesburg. Republic of South Africa.

[9] James Green (1987). Radical History Review. In Bellinda Bozzoli Editor. Ravan Press. Johannesburg. Republic of South Africa.

[10] Bellinda Bozzoli Ed. (1987). Class, Community and Conflict: South African Perspectives. Ravan Press. Johannesburg. Republic of South Africa.

[11] Aljazeera News (2015) Small Business in Thailand. February. Doha. United Arab Emirates.

[12] Martinussen, J. (2004). Society, State and Market. A guide to Competing Theories of Development. Human Sciences Research Council. Pretoria. South Africa. Published for Zed Books Ltd. London and New York.

[13] Shaikh, A; Jadwat, Z; Asvat, R; Karodia, A; and Soni, D. (2015). Centre For Entrepreneurship: Draft Strategic Plan. Regent Business School. Durban. Republic of South Africa. 
[14] Shaikh, A; Karodia, A; David, J; and Soni, D. (2015). Private Providers Can Widen Access to Higher Education in South Africa: A Fertile Idea Whose Time has Come. Press Release. Regent Business School. Durban. Republic of South Africa.

[15] Karodia, A; and Soni, D (2013). The Inextricable Relationship between the Apartheid State and Public Sector Chaos in South Africa. Internal Journal of Development Research and Quantitative Techniques. 3 (2). Autumn. Brow Walker Publications. Unite States of America.

[16] South African Broadcasting Corporation News (2015). Concessions to small businesses required urgently in South Africa. SABC Johannesburg. Republic of South Africa. February.

[17] Mchunu, S. (2014). Entrepreneurship key to local renaissance and further afield: Economic revival. Business Report. Opinion and Analysis. November 16. Johannesburg. South Africa. Page 3.

[18] Gedeon, S (2010). What is Entrepreneurship? Entrepreneurial Practice Review 1.

[19] ACS, Z. (2006). How is entrepreneurship good for economic growth? Innovations: Technology, Governance, Globalization. 1 -97-107.

[20] Paresh Soni; and Karodia, A. (2014). Entrepreneurship and Economic Development. Kuwait Chapter of Arabian Journal of Business and Management Review. Vol. 3. No. 9. May.

[21] Van Praag, C. M; and Versloot, P. H. (2007). What is the value of entrepreneurship? A review of recent research. Small Business Economics. 29. $351-382$.

[22] Berglund, H. (2005). Toward a Theory of Entrepreneurial Action: Exploring Risk, Opportunity and Self in Technology Entrepreneurship. 2.

[23] Sengupta, U; and Andy Ranachan. (2015). Business Schools as Change Agents in Low Income Communities. Rotman School of Management and Toronto's Regent Park Neighbourhood. Ontario Institute of Studies in Education, University of Toronto; Rotman School of Management. University of Toronto. The Linden School. Toronto. Canada.

[24] Masten (1993); and Marbley, (2006). Crain's New York Business, (2012). In Sengupta, U; and Andy Ranachan 23 above. University of Toronto. Canada.

[25] SABC News Discussion (2015). Panel discussion by youth on South African entrepreneurial activity. February 20. Johannesburg. Republic of South Africa.

[26] Nkosi, B. (2015). When learning's door gets bolted. Mail and Guardian. Education. Johannesburg. South Africa. February 20 to 26. Page 11.

[27] Shaikh, A; Karodia, A; Joseph, D; and Asvat, R. (2015). Advocating for a Paradigm Shift in Entrepreneurship Innovation and SMME Development in South Africa: The Role of Technology Transfers and Turnkey Operations. Regent Business School. Durban. South Africa. Press Release. February 27. Pages 1 - 7.

[28] Jordan, M. (2015). Bridge the vast university divide. Mail and Guardian. Johannesburg. South Africa. February 27 to March 5. Page 37. 